\title{
Active search of women as an efficacy factor for a breast and cervical cancer screening program in the city of Jundiaí, São Paulo, Brazil
}

\author{
Busca ativa de mulheres como fator de eficácia de programa de rastreamento de câncer de \\ mama e colo uterino no município de Jundiaí
}

\author{
João Bosco Ramos Borges ${ }^{1}$, Renata Guarisi² ${ }^{2}$ Andressa de Araújo Lacerda ${ }^{3}$, Juliana Letícia Poli ${ }^{4}$, \\ Pítia Cárita de Godoy Borges ${ }^{5}$, Sirlei Siani Moraes ${ }^{6}$
}

\begin{abstract}
Objective: To compare the profile of women looking for gynecological care to the profile of women invited to participate in the program, assessing breast and cervical cancer risk factors in each group and comparing Papanicolaou's test and mammography results. Methods: Medical records of 46 women participating in a breast and cervical cancer prevention program and 42 medical reports of women that regularly visited the primary healthcare unit from August to December 2006 were examined. Results: The mean interval between the last Papanicolaou's tests was of approximately 19.7 months when comparing women visiting their physician and 25.3 participants in the program. There was one case $(1.1 \%)$ of high grade intraepithelial lesion in one woman included in the program. Regarding breast cancer, when comparing both groups, we verified that all women above the age of 40 years that participated in the program underwent mammography; this was not verified in the group seeing a physician. This shows the efficacy of this screening, actively looking for women in the age group at risk for breast cancer. Conclusions: Active search is important to recruit women; the screening program needs improvement to show its real impact on morbidity and mortality of these cancers.
\end{abstract}

Keywords: Mass screening; Evaluation of the efficacy-effectiveness of interventions; Vaginal smears; Mammography; Breast neoplasms; Uterine cervical neoplasms; Breast cancer prevention; Cervix neoplasm prevention; Patient acceptance of health care/ethnology

\section{RESUMO}

Objetivo: Comparar o perfil das mulheres que buscam atendimento ginecológico ao perfil de mulheres convidadas a participarem do programa, avaliando-se fatores de risco para câncer de mama e de colo uterino presentes em cada grupo e comparando os resultados dos exames de Papanicolaou e mamografia. Métodos: Foi realizado levantamento de 46 prontuários de mulheres de um programa de prevenção de câncer de colo do útero e mama e de 42 prontuários de pacientes que consultaram rotineiramente 0 médico da unidade básica de saúde entre agosto e dezembro de 2006. Resultados: Constatou-se que 0 intervalo médio entre os dois últimos exames de Papanicolaou foi de aproximadamente 19,7 meses entre as mulheres que consultaram o médico e 25,3 entre as participantes do programa. Houve um caso $(1,1 \%)$ de lesão intraepitelial de alto grau em uma paciente incluída no programa. Com relação ao câncer de mama, comparando-se os dois grupos, observou-se que todas as mulheres acima de 40 anos do Grupo Programa realizaram mamografia, 0 que não ocorreu no Grupo Médico. Isso mostra a eficiência do programa de rastreamento na busca ativa de mulheres que se encontram na faixa etária de risco para 0 câncer de mama. Conclusões: A busca ativa é importante para o recrutamento de mulheres, havendo necessidade de aprimorar o programa de rastreamento para evidenciar seu impacto na morbiletalidade das doenças.

Descritores: Programas de rastreamento; Avaliação de eficáciaefetividade de intervenções; Esfregaço vaginal; Mamografia; Neoplasias da mama; Neoplasias do colo do útero; Prevenção de câncer de mama; Prevenção de câncer de colo uterino; Aceitação pelo paciente de Cuidados de Saúde/etnologia

\section{INTRODUCTION}

Both breast and cervical cancer are important causes of death in women. In Brazil, according to data from the

\footnotetext{
Study carried out at Faculdade de Medicina de Jundiaí - FMJ, Jundiaí (SP), Brazil.

${ }^{1}$ Full professor of Gynecology at Faculdade de Medicina de Jundiaí - FMJ, Jundiaí (SP), Brazil.

${ }^{2}$ Collaborating lecturer of Gynecology, Faculdade de Medicina de Jundiaí - FMJ, Jundiaí (SP), Brazil.

${ }^{3}$ Medical student, Faculdade de Medicina de Jundiaí - FMJ, Jundiaí (SP), Brazil.

${ }^{4}$ Medical student, Faculdade de Medicina de Jundiaí - FMJ, Jundiaí (SP), Brazil.

${ }^{5}$ Collaborating lecturer of Gynecology, Faculdade de Medicina de Jundiaí - FMJ, Jundiaí (SP), Brazil.

${ }^{6}$ Statistitian, Universidade Estadual de Campinas - UNICAMP, Campinas (SP), Brazil.

Corresponding author: João Bosco Ramos Borges - Rua Francisco Telles 250 - Vila Arens - CEP 13202-550 - Jundiá (SP), Brazil - Tel.: 45871095 - e-mail: drbosco@terra.com.br

Received on Aug 7, 2009 - Accepted on Dec 18, 2009
} 
Instituto Nacional de Câncer (National Cancer Institute, INCA), the estimated number of new cervical cancer cases in 2008 was of 18,680 , with an estimated risk of 19 cases in every 100 thousand women ${ }^{(1)}$. In the city of Jundiaí, the mortality rate of cervical cancer increased from 2.91/100,000 women in 2004 to $3.34 / 100,000$ women in $2005^{(2)}$.

The main agent causing cervical cancer is human papillomavirus (HPV) and its infection represents the most important sexually transmitted disease (STD) worldwide. Several HPV subtypes can cause cancer, especially HPV 16 and $18^{(3)}$. Its prevalence reaches $25 \%$ in women aged from 15 to 25 years $^{(4)}$. Other risk factors include low socioeconomic status, precocious sexual activity initiation, many sex partners, and being multiparous ${ }^{(5-6)}$. Tobacco smoking has also been mentioned as a risk factor, related mainly to high grade lesions ${ }^{(7-9)}$.

In order to obtain a successful early diagnosis, organized, highly-effective and low-cost screening programs should be implemented ${ }^{(10)}$ based on Papanicolaou's test (cervical oncology tests), and including the greatest possible number of women at risk $^{(4,11)}$. According to the World Health Organization (WHO), covering an extense population (80\%) has a great impact in reducing the incidence of invasive tumors, and a $90 \%$ drop of this disease is expected due to early detection ${ }^{(12)}$.

Likewise, breast cancer is one of the major public health problems not only in developing countries, such as Brazil, but also in developed countries. This fact is due to difficulties in primary prevention, incurring in a significant increase in incidence and mortality rates due to this cancer ${ }^{(13)}$.

According to INCA, new breast cancer cases estimated in Brazil, in 2008, reached 49,400 women with an estimated risk of 51 cases per 100 thousand women. In the Southeastern region, this is the cancer of highest incidence with an estimated risk of 68 new cases per 100 thousand women ${ }^{(1)}$. In the city of Jundiaí, 56 new breast cancer cases were diagnosed in 2006, with a mortality rate of 18.6 deaths per 100,000 inhabitants. In that year, the mammography rates were very low; only 546 mammography tests were performed per month ${ }^{(14)}$.

Monthly breast self-examination is still a valid strategy to be used in developing countries as a safe, lowcost, secondary prevention that can improve diagnosis staging. Additionally, mammography is very important in screening breast cancer, although the coverage is far from ideal in the State of São Paulo.

A study carried out by Borges et al. in Jundiaí showed that, if a physician orients patients to perform breast self-examination, the rate of this method increases 3.3 times when compared to patients not receiving such advice. This result is also associated with mammography, since over $53 \%$ of women performing the monthly self-examination had already undergone mammography, while more than $56 \%$ who did not perform self-examination had never been submitted to mammography. It shows that instructions given by a physician are essential to the habit of self-examinations, as well as undergoing mammography ${ }^{(15)}$.

Considering that breast and cervical cancer account for approximately one fourth of women's deaths in the city of Jundiaí, the Secretariat of Health, with the support of the Department of Gynecology and Obstetrics of Faculdade de Medicina de Jundiaí (Medical School), developed an Organized Screening Program for breast and cervical cancer precursor lesions.

This program is in the initial assessment phase and actively invites women to undergo Papanicolaou's smears and, for those older than 40 years, to be submitted to mammography. Women are invited to participate by a letter delivered at their houses by a community healthcare agent during the month of their birthday. The previously trained nurse of each Primary Healthcare Unit (PHU) collects the history, performs the physical examination of the breasts, collects the Pap smear and requests mammography when necessary. Women with abnormal tests are sent to the Women's Health Outpatients Clinic and are managed according to the cervical lesion and altered mammography protocols. This pilot program was carried out in the PHUs in the districts of Morada das Vinhas and Vila Ana, in Jundiaí (SP), Brasil.

\section{OBJECTIVES}

To compare the profile of women who seek care at the PHU to the profile of women invited to participate in the Program, assessing risk factors for breast and cervical cancer in each group and comparing the test results (Papanicolaou's smear and mammography) of both groups.

\section{METHODS}

This is a descriptive and analytic cross-sectional study. The study project was approved by the Ethics Committee of Faculdade de Medicina de Jundiaí.

From August to December 2006, when the Program was started, a survey was undertaken at the PHU in the district of Morada das Vinhas to verify data from 46 medical records of women who had received the invitation letter and from 42 records of women routinely seen by the PHU physicians.

The profile of women accepting the invitation and of those routinely seen by the physician was outlined through analysis of history upon examination, and then a specific form was filled in. This form contained information about age, schooling level, marital status, 
race, date of last menses, pregnancy during the study period, age at first intercourse, number of sex partners, sexually transmitted diseases (STD) history, number of pregnancies, contraceptive methods, previous cancer screening cytology, personal history of STD, HPV, smoking, personal or family history of breast cancer, as well as results of Schiller test, visual inspection with acetic acid, Papanicolaou's test and mammography.

Two databases were organized with information about women enrolled in the Program (Program Group) and of those routinely seen by the physician (Physician Group). Data were described by means, standard deviation and median. Statistical tests were performed to assess differences between women routinely visiting the PHU and women invited to participate in the Program. The Mann-Whitney test was used to assess interval variables, since the variables could not be studied by Shapiro-Wilks normality test. The prevalence was analyzed by the Fisher's exact test. The significance level was set at $5 \%$.

A linear regression analysis was performed (because most independent variables analyzed were numerical) with stepwise selection criteria in order to determine the most important characteristics. The statistical regression model was significant $(p=0.0020)$ with a determination coefficient (R2) of 0.833 , which demonstrates that it was a statistically consistent method.

\section{RESULTS}

The following profile characteristic of 88 patients studied should be mentioned: $75.4 \%$ were Caucasian and $18 \%$ Black; most of them were married (67.1\%) and non-smokers $(69.3 \%)$. The median age was 35.9 years and the mean schooling was 8.5 years.

As to their gynecological features, the median age at first sexual intercourse out of 67 women was 18 years old; the median number of sexual partners since the first intercourse and during the last 12 months was one. Only one woman had previous history of STD and none reported previous HPV infection. The same rate was found when assessing STD in partners: only one subject reported a partner with previous STD. The preferred contraception was the hormonal method (35\%), followed by ovarian tube ligation $(11.3 \%)$, condoms $(10 \%)$ and others $(11.3 \%)$.

Comparing the sociodemographic characteristics of patients participating in the Screening Program with those that routinely saw their physician, there was no significant difference regarding marital status, race, smoking and/or drug abuse. The same is true for past gynecologic history.

As to obstetric history, the mean number of deliveries was higher in the Physician Group (2.7) than in the Program Group (1.8); this difference was statistically significant $(\mathrm{p}=0.0301)$. Likewise, a higher number of vaginal deliveries was found in the Physician Group ( $\mathrm{p}=0.0077)$ (Table 1).

Most patients $(94.9 \%)$ had undergone previous cancer screening cytology and four patients who had never been submitted to it were enrolled in the Screening Program (Program Group). The mean interval between the last two Papanicolaou smears was approximately 19.7 months in the Physician Group and 25.3 months in the Program Group; this difference was statistically significant $(\mathrm{p}=0.0459)$ (Table 1$)$.

Table 1. Comparison of the clinical and epidemiological variables between the Physician and Program Groups of women seen at the PHU Morada das Vinhas, Municipality of Jundiaí, in the period from August to December 2006 ( $n=88$ )

\begin{tabular}{|c|c|c|c|c|c|c|c|c|c|}
\hline \multirow[b]{2}{*}{ Variable } & \multicolumn{4}{|c|}{ Physician } & \multicolumn{4}{|c|}{ Program } & \multirow[b]{2}{*}{ p value } \\
\hline & $\mathbf{n}$ & Mean & $\begin{array}{l}\text { Standard } \\
\text { deviation }\end{array}$ & Median & $\mathbf{n}$ & Mean & $\begin{array}{l}\text { Standard } \\
\text { deviation }\end{array}$ & Median & \\
\hline Age & 42 & 36.3 & 13.6 & 34.7 & 46 & 37.4 & 13.6 & 36.6 & 0.6681 \\
\hline Schooling (years) & 28 & 9.2 & 2.9 & 11.0 & 36 & 8.1 & 3.3 & 8.0 & 0.1233 \\
\hline Age at first sexual intercourse & 31 & 18.9 & 4.3 & 18.0 & 36 & 18.0 & 2.4 & 18.0 & 0.8599 \\
\hline Number of gestations & 42 & 2.4 & 2.2 & 2.0 & 38 & 1.9 & 1.6 & 2.0 & 0.4128 \\
\hline Number of deliveries & 31 & 2.7 & 2.0 & 3.0 & 32 & 1.8 & 1.3 & 2.0 & 0.0301 \\
\hline Number of miscarriages & 10 & 1.3 & 0.5 & 1.0 & 13 & 0.8 & 1.1 & 1.0 & 0.0663 \\
\hline Number of $\mathrm{C}$-sections & 17 & 1.8 & 0.8 & 2.0 & 17 & 1.4 & 1.2 & 1.0 & 0.2410 \\
\hline Number of vaginal deliveries & 18 & 3.0 & 2.0 & 3.0 & 21 & 1.6 & 1.4 & 2.0 & 0.0077 \\
\hline Number of sexual partners since first intercourse & 28 & 1.8 & 1.1 & 1.0 & 33 & 2.2 & 2.5 & 1.0 & 0.8544 \\
\hline Number of sexual partners in the past 12 months & 29 & 0.9 & 0.3 & 1.0 & 35 & 0.9 & 0.4 & 1.0 & 0.8232 \\
\hline Time of hormonal contraception (months) & 9 & 55.7 & 74.4 & 36.0 & 14 & 49.4 & 65.4 & 30.0 & 0.8759 \\
\hline Time since last oncologic cytology (months) & 35 & 19.7 & 14.6 & 15.0 & 38 & 25.3 & 43.8 & 12.0 & 0.0459 \\
\hline Cigarettes/day & 11 & 10.5 & 6.9 & 10.0 & 12 & 14.5 & 16.3 & 8.5 & 0.8524 \\
\hline Smoking time (years) & 8 & 13.8 & 12.5 & 8.0 & 8 & 15.8 & 9.6 & 17.5 & 0.7533 \\
\hline Time since quitting smoking (years) & 2 & 5.0 & 4.2 & 5.0 & 3 & 9.7 & 8.3 & 7.0 & 0.7872 \\
\hline
\end{tabular}

*Mann-Whitney test 
When assessing the Papanicolaou results of both groups, $86.25 \%$ of the tests were normal, $5 \%$ showed vaginal flora alterations (Candida, Gardenella, among others), and one "Program" patient (1.25\%) presented high-grade intraepithelial lesion (HGIL) (Figure 1).

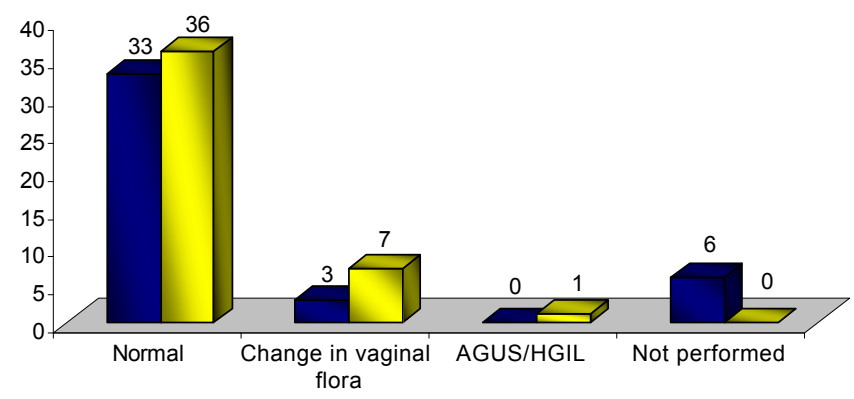

- Physician Group aProgram Group

AGUS/HGIL: atypical glandular cells of undetermined significance/high grade glandular intraepithelial lesion

Figure 1. Oncologic cytology results from patients in the Program and Physician Groups seen at the PHU Morada das Vinhas, Municipality of Jundiaí, in the period from August to December 2006 ( $n=88$ )

All 46 women of the Program Group did the Pap smear and in only two patients the results were not available. Results were normal in most tests performed in the three age groups (81.8\%), with only one case of atypical glandular cells of undetermined significance AGUS/HGIL in a 45-year-old woman (Figure 2).

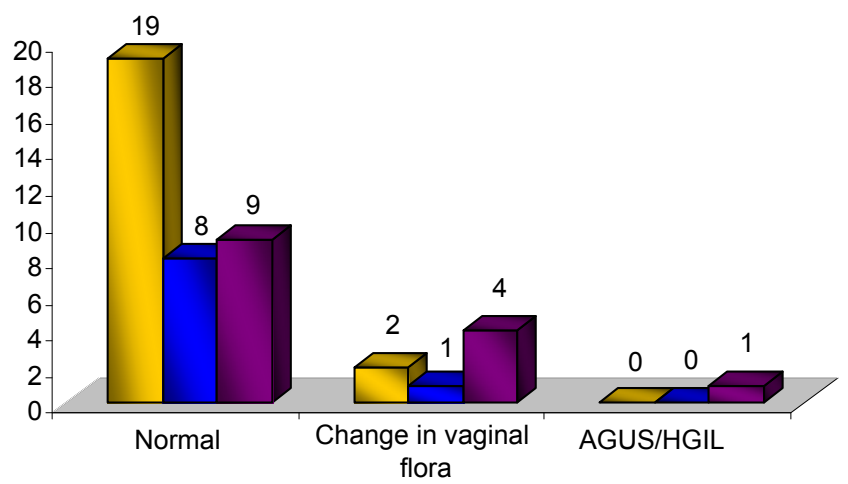

$$
\square<35 \text { years } \square 35-44 \text { years } \square>45 \text { years }
$$

AGUS/HGIL: atypical glandular cells of undetermined significance/high grade glandular intraepithelial lesion

Figure 2. Distribution of women in the Group Program submitted to oncologic cytology per age group, seen at the PHU Morada das Vinhas, Municipality of Jundiaí, in the period from August to December 2006

When comparing these data with data from the Physician Group, most of 42 patients $(78.75 \%)$ also had normal cytology. However, 6 women of this group $(16.66 \%)$ did not perform the test: two were in the age group $<35$ years and 4 were older than 45 years.
The analysis of history of breast cancer revealed that $2.7 \%$ of patients had a positive personal history and $10.7 \%$ had a positive family history. There were no significant differences between the groups $(\mathrm{p}>0.05)$. All patients older than 40 years (total $=18$ ) enrolled in the "Program" were submitted to mammography during the study period.

In the Physician Group, out of 16 patients, 3 (18.75\%) had not been submitted to mammography during the same period (Figure 3). Among 88 patients included in this study, $95.12 \%$ had normal mammography results (BIRADS I and II). Most women (47.72\%) were not submitted do mammography in the study period and those who did it generally belonged to "Program" group. There were no significant differences between mammographic results in both groups $(\mathrm{p}=0.367)$.

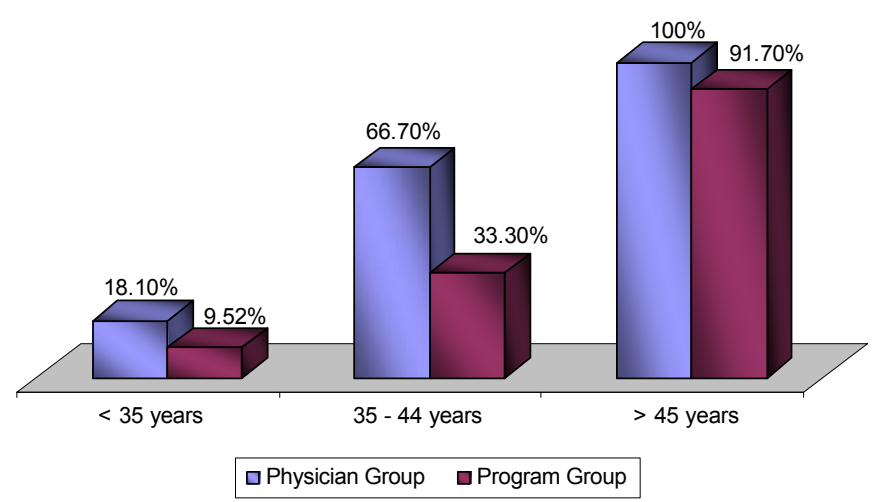

Figure 3 - Distribution of women in the Program and Physician Groups submitted to mammography per age group, seen at the PHU Morada das Vinhas, Municipality of Jundiaí, in the period from August to December 2006

Among the variables studied by a multivariate regression model, the following were related to the patient profile ("Program" and "Physician" groups): marital status, age when starting sexual activity, current number of partners, previous oncologic cytology, clinical examination of breasts, and schooling; all positively correlated to the dependent variable "Program", except schooling (negative correlation).

"Program" patients have less years of education than those of the Physician Group; marriage is positively related to participating in the "Program". The higher the age at starting sexual activities, the greater is the correlation with the Program Group, and the higher the BIRADS score, the grater the chance to belong to the Screening Program (Table 2).

Among the variables selected by the method, the most important correlations within the Physician Group were: having done previous oncologic cytology, to be married (probably related to a single partner and less partners), because these variables obtained the highest estimated parameter values (Table 2). 
Table 2. Comparing some variables in the Program and Physician Groups through a multivariate regression model

\begin{tabular}{lcccc}
\hline Independent variable & $\begin{array}{c}\text { Estimated } \\
\text { parameter }\end{array}$ & $\begin{array}{c}\text { Standard } \\
\text { error }\end{array}$ & p value & partial R \\
\hline Intercept & -4.37 & 0.96 & 0.0011 & - \\
Marital status - married & 0.66 & 0.15 & 0.0014 & 0.101 \\
Age at first sexual intercourse & 0.11 & 0.03 & 0.0047 & 0.144 \\
Number of current sexual & 0.43 & 0.13 & 0.0083 & 0.179 \\
partners & & & & \\
Previous oncologic cytology & 1.35 & 0.28 & 0.0006 & 0.161 \\
Breast examination & 0.47 & 0.13 & 0.0039 & 0.090 \\
(increasing BIRADS class II or & & & & \\
nodule) & & & & \\
Years of study & -0.26 & 0.05 & 0.0004 & 0.159 \\
Statistical Model & & & 0.0020 & 0.833 \\
\hline
\end{tabular}

Significance level: 0.05

Dependent variable: Program

Independent variables: Age, marital status, gestation upon appointment, number of gestations, schooling (years) age at first sexual intercourse, number of current sexual partners, number of sexual partners in the past 12

months, partner with STD, type of contraceptive method, time of hormonal contraception, personal history of STD, previous oncologic cytology (OC), history of HPV, smoking, drug abuse, personal history of breast cancer, family history of breast cancer, $\mathrm{OC}$ result, clinical examination of breasts.

\section{DISCUSSION}

According to the results of this study, longer periods of intervals were found in the last two oncologic cytologies in the Program Group, thus demonstrating the importance of implementing a Screening Program, because, probably, these women only did the Papanicolaou smear due to invitation by healthcare agents. Therefore, it can be stated that the Program fulfilled its expected role. It has to be improved and expanded, thus reducing cervical cancer rates in this municipality.

In some European Union countries such as Iceland, Sweden, Finland, and United Kingdom, where cytopathological screening has been the main strategy to control this disease, significant drops in incidence and mortality due to cervical cancer have been observed. Generally, the success of such programs is related to factors such as effective coverage of the population at risk, quality of specimen collection and interpretation of results, as well as adequate treatment and follow-up ${ }^{(16)}$.

Regarding cytology results, only one case of HGIL was found in the Program Group, specifically in a Caucasian, married, illiterate, smoker 66-year-old woman who were in menopause for 8 years, started sexual activities at the age of 21 years, was nulliparous, had one sole sexual partner since her first intercourse, only two previous oncologic cytologies, the last one performed ten years ago.

It shows the importance of the Screening Program, which aims primarily at active search for patients that have been excluded from healthcare actions and who do not receive adequate information about the importance of routine Papanicolaou smears to diagnose cancer precursor lesions. When comparing the profile of the studied patients to the literature data, it was noticed that this sample did not have some of the main risk factors for cervical cancer, such as early sexual activity, being multiparous, and having several sexual partners. However, some authors mentioned smoking as a factor specially connected to high grade lesions ${ }^{(7-9)}$.

Based on these results, this woman was sent to the Cervical Pathology Unit (Women's Health), where she underwent colposcopy and guided biopsy. With the diagnosis of in situ cervical cancer, she was submitted to cervical conization by high frequency surgery and is now cured and undergoing follow-up. According to the literature, high frequency surgery (HFS) is the appropriate treatment for about $80 \%$ of the affected women $^{(16)}$.

A significant difference found among the groups was the number of gestations; those enrolled in the Physician Group had more pregnancies when compared to the Program Group. This results show that women are more concerned with pregnancies than with cervical cancer; they see their physician to carry out prenatal tests and, therefore, preventive tests are carried out. Thus, health education encouraging women to see a physician for prevention and not only occasionally during pregnancy is of the utmost importance. Continued education for physicians of the public healthcare network is also important to emphasize the need of cytology in pregnant women.

Only a small percentage had a family history of breast cancer. According to literature, women whose aunt or grandmother had breast cancer are at a oneto-two-fold greater risk of developing the same cancer, although only $10 \%$ of breast cancer patients have a positive family history ${ }^{(17)}$.

The mammography results were negative for breast cancer. Most patients did not undergo mammography, but the majority of women of this sample were younger than 40 years old, an age group to which this screening is not applicable. Comparing both groups, it was seen that all "Program" women above older than 40 years old were submitted to mammography, whereas in the Physician Group, 3 out of 16 patients in the same age group were not. This shows efficacy of a Screening Program actively reaching out for women in the age range at risk for breast cancer.

\section{CONCLUSIONS}

The results allow the conclusion that an active search for women aiming at their participation in a Screening Program is extremely important for early diagnosis and better prognosis of breast and cervical cancer. Therefore, Screening Programs have to be improved all over the municipality of Jundiaí to demonstrate its true impact on the morbidity and mortality of these severe diseases. 


\section{REFERENCES}

1. Brasil. Ministério da Saúde [Internet]. Estimativa câncer no Brasil 2008. [citado 2008 Jul 1]. Disponível em: http://www.inca.gov.br/estimativa/2008/ versaofinal.pdf.

2. Brasil. Ministério da Saúde [Internet]. Indicadores Municipais de Saúde. Município: Jundiaí, SP. 2006. [citado 2010 Fev 11]. Disponível em: http:// portal.saude.gov.br/portal/aplicacoes/tabfusion/tabfusion.cfm.

3. Soler ME, Gaffikin L, Blumenthal PD. Cervical cancer screening in developing countries. Prim Care Update Ob Gyns. 2000;7(3):118-23.

4. Syrjänen K, Syrjänen S. Papillomavirus Infections in Human Pathology. New York: J. Wiley \& Sons; 2000. Chapter 4. Diagnostic techniques in HPV detection; p. 89-116.

5. International Training for Health. Causes, prevention and detection of cancer of the uterine cervix in developing countries. Draft 3. [Training Informatin Packet]. ChapeHill, USA, 1995.

6. Parkin DM, Bray FI, Devesa SS. Cancer burden in the year 2000. The global picture. Eur J Cancer. 2001;37 Suppl:S4-S66.

7. Derchain SF, Roteli-Martins CM, Syrjänen KJ, de Abreu HJ, Martinez EZ, Alves VA. Association of oncogenic human papillomavirus DNA with high grade cervical intraepithelial neoplasia: the role of cigarette smoking. Sex Transm Infect. 1999;75(6):406-8.

8. Kjellberg L, Hallmans G, Ahren AM, Johansson R, Bergman F, Wadell G, et al. Smoking, diet, pregnancy and oral contraceptive use as risk factors for cervical intra-epithelial neoplasia in relation to human papillomavirus infection. $\mathrm{Br} \mathrm{J}$ Câncer. 2000;82(7):1332-8.
9. Samur EA, Urteaga CR, Rebolledo AA, Villegas RA, Lois EM, Juhasz AC. Alimentación, tabaquismo e historia reproductiva como factores de riesgo del cáncer de cuello del útero. Rev Méd Chile. 2001;129(6):597-603.

10. Smith RA, Cokkinides V, Eyre HJ. American Cancer Society. American Cancer Society guidelines for the early detection of cancer, 2003. CA Cancer J Clin. 2003:53(1):27-43.

11. Franco EL. Understanding the epidemiology of genital infection with oncogenic and nononcogenic human papillomaviruses: a promising lead for primary prevention of cervical cancer. Cancer Epidemiol Biomarkers Prev. 1997;6(10):759-61.

12. Brasil. Ministério da Saúde. Instituto Nacional do Câncer. Periodicidade de realização do exame preventivo do câncer dc colo do útero: normas e recomendações do INCA. Ver Bras Cancerol. 2002;48(1):13-15.

13. Gebrim LH, Quadros LGA. Rastreamento do câncer de mama no Brasil. Rev Bras Ginecol Obstet. 2006;28(6):319-23.

14. Estimativa Populacional por Micro-regiões do Estado de São Paulo, 2003. [citado 2006 Jun 1]. Disponível em: www.abep.nepo.unicamp.br/docs/anais/ pdf/2000/.../prot20_1.pdf

15. Borges JBR, Morais SS, Borges TG, Guarisi R, Maia EMC, Paganotti JC, et al. Perfil das mulheres no município de Jundiaí quanto ao hábito do auto-exame das mamas. Rev Bras Cancerol. 2008;54(2):113-22.

16. Instituto Nacional do Câncer (Brasil). Câncer de colo de útero e mama. 2006. Disponível em: www.inca.gov.br/conteudo_view.asp?id=1796

17. Souza RM, Lazzaron AR, Defferrari R, Borba AA, Scherer L, Frasson AL. História familiar em segundo grau como fator de risco para câncer de mama. Rev Bras Ginecol Obstet. 1998;20(8):469-73. 